\title{
疫学・画像・病理組織学的解析を駆使した心臟サルコイドーシスの多面的臨床 研究
}

\author{
永井利幸 ${ }^{1)}$
}

\section{【要旨】}

我々は心臟サルコイドーシス（心サ症）の診療および臨床研究に10年以上従事し, 国内外の専門誌に研究成果を発表して きた．まず，画像的検討に関して，心臟外サ症におけるガドリニウム遅延造影心臟MRIを用いて検出した心臟微小病変は平 均50 カ月の有害事象発生と関連しない可能性を示した。 また, 疫学的検討として心症診断時の免疫抑制療法の導入が長 期にわたり心機能を保持し，心不全入院を抑制していたことを明らかにした，その上，免疫抑制療法が開始され，その後安 定した経過をたどり免疫抑制療法を途中中止した症例は有意に心臟死の頻度が高く，心機能も経時的に低下することも明ら かにした. 病理組織学的検討では, 心症における免疫応答機構に樹状細胞と M1 タイプの炎症性マクロファージが強く関 与していること, 非肉芽腫組織に浸潤するこれら免疫細胞が心臟サルコイドーシスの新たな病理組織学的診断マーカーにな りうることを示した。

キーワード：心臟サルコイドーシス，診断，治療，予後

[日サ会誌 2021; 41: 3-8]

\section{Epidemiological, imaging and histopathological studies for cardiac sarcoid- osis}

Toshiyuki Nagai ${ }^{1)}$

Keywords: cardiac sarcoidosis, diagnosis, treatment, prognosis

\section{はじめに}

わが国の難病に指定されている全身性肉芽腫疾患であ るサルコイドーシスの死因の約半数は心臟病変 (心臟サル コイドーシス）によるものであり，心臟病変の早期診断・ 治療が患者の予後改善のために極めて重要である ${ }^{1)}$ ．著者 は 10 年以上にわたり，本症の診療および研究に携わって きた。

心臓外サルコイドーシス症例におけるガドリニウ 么遅延造影心臓磁気共鳴画像を用いた心臓病変の 早期検出と予後的意義

サルコイドーシスにおいて心臟病変の合併は最大の予 後規定因子とされている．2000年代に入り，ガドリニウム 遅延造影心臟磁気共鳴画像 (late gadolinium enhancement cardiac magnetic resonance imaging: LGE-CMR）を用い た微小心筋障害の検出が可能となり，著者はLGE-CMRに 着目し，心臟外病変を有するサルコイドーシス患者におい て, 心臟病変の早期発見が可能か前向きに検討した。臟 外臟器でサルコイドーシスと臨床あるいは病理学的に確
定診断され，心臟病変を示唆する所見を認めない 61 例に LGE-CMRを施行したところ，8例（13\%）にLGE陽性所 見を認めた. さらに, 登録された全例を平均 50 力月追跡 し, 微小な心筋障害がその後の有害事象には必ずしもつな がらない可能性を示唆し, 一部の症例では免疫抑制療法を 早期に施行し，心筋障害の改善を認めたことを報告した (Figure 1) ${ }^{2}$. 米国症例を対象とした同様の検討では19〜 $26 \%$ にLGE陽性を認め, イベント発生率も平均 $21 \sim 22$ カ 月の観察期間で $9.8 \sim 9.9 \%$ と高率であった ${ }^{3,4)}$. しかしなが ら，米国症例ではLGE陽性例におけるLGE領域は我々の 検討と比較すると広範囲であり, 広範なLGEがその後の 不良な臨床転帰と関連していることが示唆され，その後の 検討に扔いて特にLGE $\geqq 20 \%$ を有する症例はステロイド

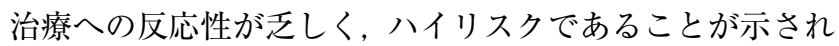
た5,6). したがって, 我々の検討と合わせると, 心蔵外サル コイドーシス症例において, 心臟病変のスクリーニングで 施行したLGE-CMRでLGE陽性を認めたとしても, LGE領 域が小さければイベント発生リスクは低く, 免疫抑制療法 によるメリットは少ないと考えられた。
1 ) 北海道大学大学院医学研究院 循環病態内科学教室

著者連絡先：永井利幸（ながい としゆき）

厂060-8638 北海道札幌市北区北15条西7

北海道大学大学院医学研究院 循環病態内科学教室

E-mail : nagai@med.hokudai.ac.jp
1 ) Department of Cardiovascular Medicine, Faculty of Medicine and Graduate School of Medicine, Hokkaido University, Hokkaido, Japan

*掲載画像の原図がカラーの場合, HP上ではカラーで閲覧できます. 


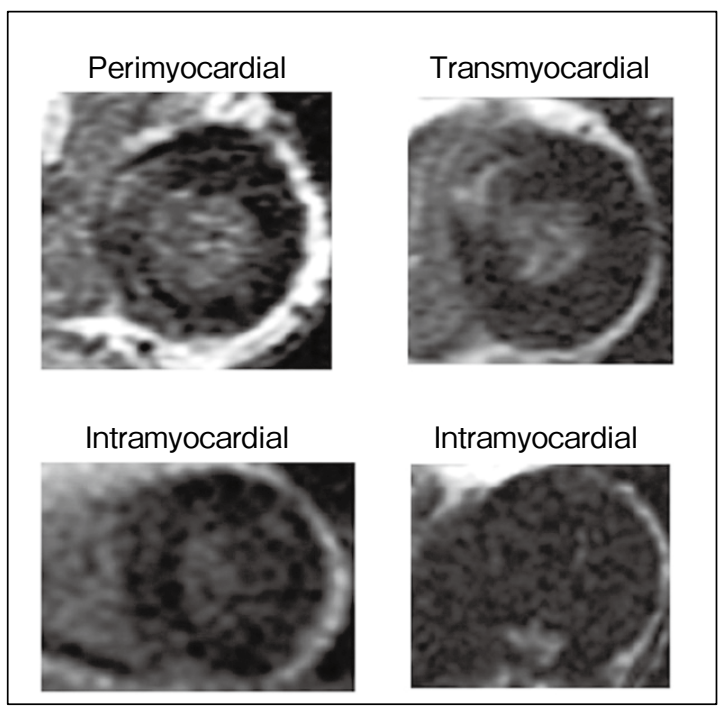

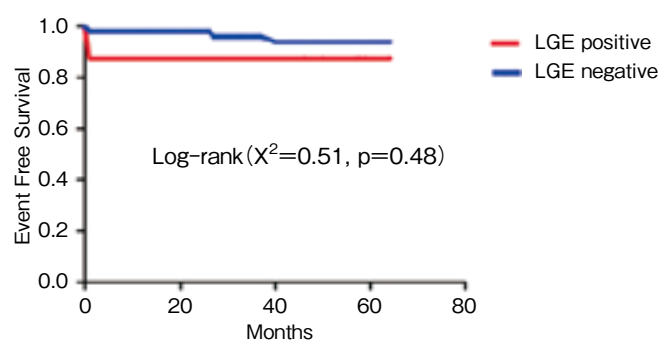

C

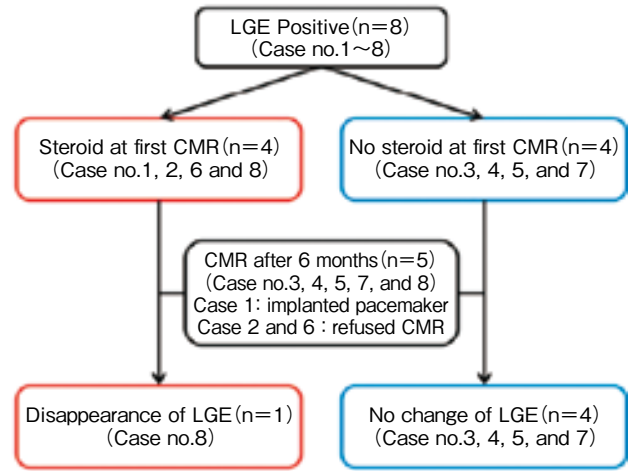

Figure 1. ガドリニウム遅延造影心臓磁気共鳴画像を用いた心臓病変の早期検出と予後的意義

（a）LGE陽性例における造影パターン.

(b) LGEの有無と有害事象.

（c）LGE陽性例におけるLGEの変化.

CMR：心臓磁気共鳴画像, LGE : ガドリニウム遅延造影.

(文献2）より引用)

\section{心臟サルコイドーシスにおける免疫抑制療法の長 期効果と途中中止による影響}

心臓サルコイドーシスに対する免疫抑制療法は標準的 治療として推奨されているものの, 本症診断時の導入の有 無が長期予後に与える効果に関するエビデンスは不十分 であった ${ }^{7)}$. 著者は国立循環器病研究センター（国循）の 過去 20 年以上にわたる後ろ向きコホートを構築し, 83 例 の心臓サルコイドーシスにおける平均 7.6 年予後を検討し た. 結果, 診断時の免疫抑制療法の導入が長期にわたり左 室収縮機能を保持し, 心不全入院を抑制していたことを明 らかにした8）。また，免疫抑制療法が開始され，その後安 定した経過をたどる症例における免疫抑制療法の中止が その後の転帰に与える影響について，同データベースを用 いて詳細に検討したところ，免疫抑制療法を途中中止した 症例は心臓死の頻度が有意に高く, 左室収縮機能も経時的 に低下することを明らかにした (Figure 2) ${ }^{9)}$.

\section{心臓サルコイドーシスにおける心室中隔基部菲薄 化の予後的意義}

心臓サルコイドーシスの診断において心室中隔基部の 菲薄化は特徴的所見とされ，診断基準の主兆候の1つであ るが，その予後的意義は不明であった．著者は国循で構築 したコホート74例の平均 5.1 年予後を後ろ向きに検討し た. 心室中隔基部菲薄化の定義は森本らによる以下の基準 を用いた ${ }^{10)}$.

基準 : 壁厚 $\mathrm{A} \leqq 4 \mathrm{~mm}$ あるいは $\mathrm{A} / \mathrm{B}$ 比 $\leqq 0.6$ ，もしくは両
方を满足する.

壁厚 $\mathrm{A}$ ：大動脈弁輪から心尖部寄りに $10 \mathrm{~mm}$ の部位. 壁厚 $\mathrm{B}$ : 心室中隔を 3 等分した基部側 3 分の 1 の部位.

結果, 心室中隔基部の菲薄化の存在は独立した心血管イ ベントの規定因子であり, 特に致死性不整脈と心不全の発 症と関連していたことを明らかにした (Figure 3 ${ }^{11)}$.

\section{心臓サルコイドーシスにおける免疫応答機構と非 肉芽腫組織における病理組織診断への応用}

心臓サルコイドーシスの診断における心筋生検の感度 は30\%以下である ${ }^{12)}$. 著者は心臓サルコイドーシスにお ける免疫応答機構に着目し, 心筋組織に浸潤する免疫応答 細胞（樹状細胞, マクロファージ）を詳細に検討すること で心蔵サルコイドーシスの組織診断精度を改善しうるか, 確診例連続95例と拡張型心筋症など非炎症性心筋症 50 例 で比較検討した. 結果, 肉芽腫の有無や各種診断基準にか かわらず, 心臓サルコイドーシス確診例の非肉芽腫組織に おけるCD209陽性樹状細胞とCD68陽性マクロファージ （全マクロファージ）の浸潤は対照群と比較して有意に多 く認められた一方, CD163陽性抗炎症性マクロファージ (M2マクロファージ) の浸潤は少なかった. 対照群との比 較において, 非肉芽腫組織に浸潤するM2/全マクロファー ジ比の減少かつ樹状細胞数の増加による心臓サルコイ ドーシスの診断感度は $46.2 \sim 65.4 \%$, 特異度は $100 \%$ と改 善し, 非肉芽腫組織に浸潤する樹状細胞とマクロファージ フェノタイプは心臓サルコイドーシス診断における新た 
a

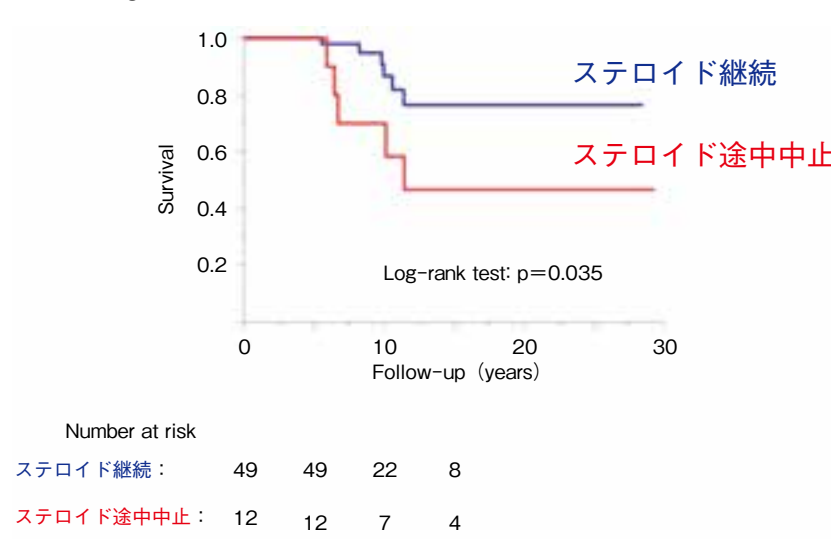

b
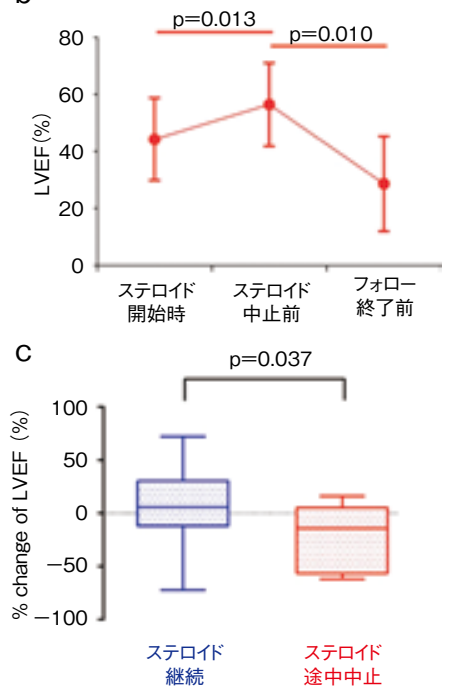

Figure 2. ステロイド途中中止と予後

(a) ステロイド途中中止の有無と心臓死.

(b) ステロイド途中中止例における左室駆出率の変化.

(c) ステロイド途中中止の有無と左室駆出率の変化率.

LVEF : 左室駆出率.

(文献9) より引用)

a

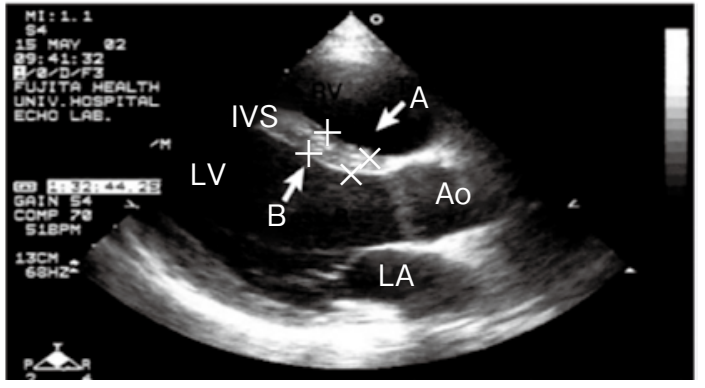

$\mathrm{A}$ ：大動脈弁輪から心尖部寄りに $10 \mathrm{~mm}$ 部位

$B$ ：心室中隔を3等分した基部側 $1 / 3$ の部位

壁厚 $\mathrm{A} \leqq 4 \mathrm{~mm}$

$\mathrm{A} / \mathrm{B}$ 比 $\leqq 0.6$

上記のどちらかまたは両者を満たす

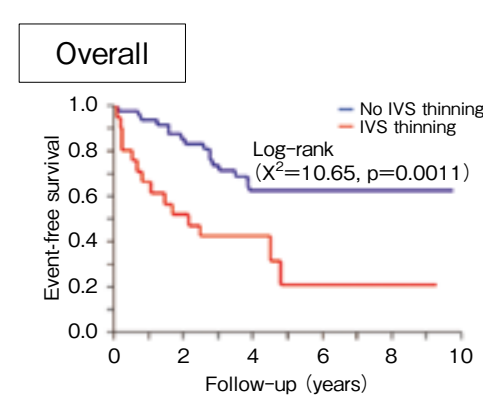

Symptomatic arrhythmia

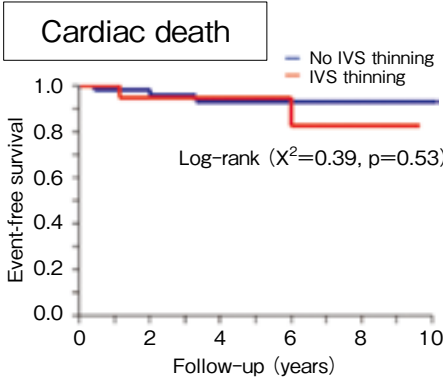

Heart failure admission

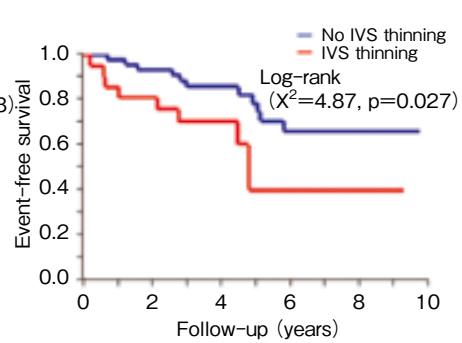

Figure 3. 心室中隔基部菲薄化の予後的意義
(a) 心室中隔基部菲薄化の定義.
（b）心室中隔基部菲薄化と予後.
IVS : 心室中隔, LV : 左室.

(文献10,11) より引用)

な病理組織学的マーカーになりうることを示した（Figure $4)^{13)}$.

\section{心臓サルコイドーシスにおける心筋生検陽性を予 測する因子}

著者は北海道大学および国循の後ろ向きコホートを統
合し, 心筋生検を施行された心臟サルコイドーシス 90 例 を対象に心筋生検陽性予測因子を検討したところ，心筋生 検施行時の $\mathrm{ACE}$ 高值 $(\geqq 13.5 \mathrm{U} / \mathrm{L})$, 左室駆出率低值 （<37\%） が心筋生検陽性の独立関連因子であることを明 らかにした ${ }^{14)}$. 
a
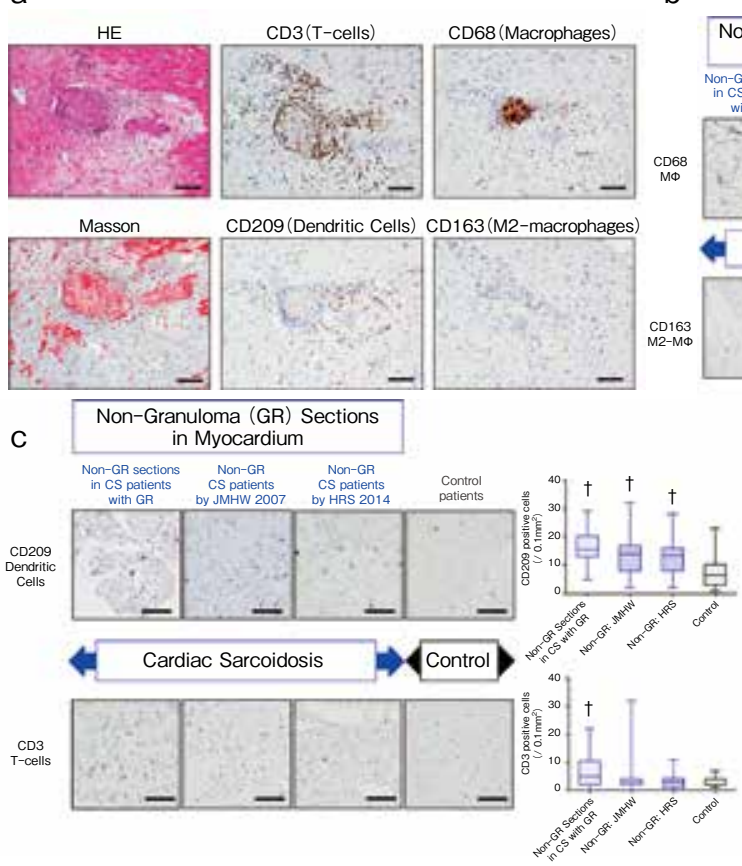

$\mathrm{b}$
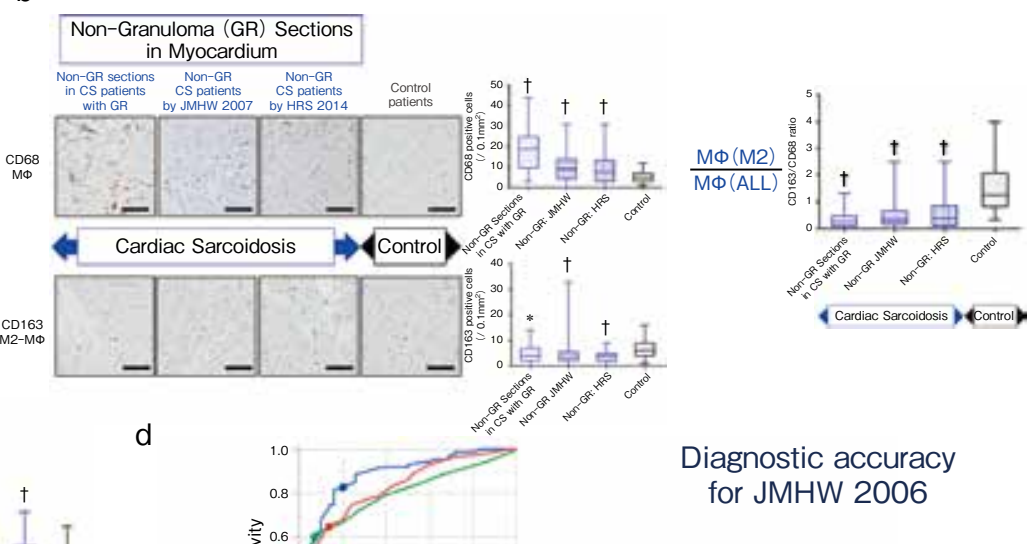

Figure 4. 心筋組織に浸潤する免疫応答細胞と診断精度

(a) 肉芽腫組織に浸潤する免疫応答細胞.

(b) 非肉芽腫組織に浸潤するマクロファージ数.

(c) 非肉芽腫組織に浸潤する樹状細胞数と Tリンパ球数.

（d）非肉芽腫組織に浸潤する免疫応答細胞数と診断精度.

JMHW : 日本国厚生労働省, MФ：マクロファージ.

(文献13) より引用)

\section{心臓サルコイドーシス診療におけるFDG-PETの 有用性と限界}

${ }^{18} \mathrm{~F}$-fluorodeoxyglucose positron emission tomography （FDG-PET）は心臓サルコイドーシスの診断そして病勢評 価に有用とされるが，著者らは最近複数回のFDG-PET陰 性が確認された心臓サルコイドーシス（組織診断群）を報 告した ${ }^{15)}$. また, 北海道大学の複数症例や国循の後ろ向き コホートを解析した結果, FDG-PETの活動性所見と臨床 的指標の乘離を認める症例が少なからず認められること を報告した ${ }^{16)}$. 免疫抑制療法中に一旦陰性化していた FDG-PET所見が陽転化したものの, 臨床上心機能悪化, 心不全あるいは不整脈イベントをまったく認めない場合 は免疫抑制療法の強化にルーチンで踏み切ることの是非 に関しては報告が極めて少なく，かつ比較的多数例での後 ろ向き検討でも担当医ごとにPET施行のタイミングや撮 像条件を含めた診療プラクテイスも様々であり, 現状は症 例ごとの判断にならざるを得ない. また，前述のように LGEの集積範囲が有害事象リスクと関連していることは 明らかになっており, PETとCMRの予後的意義における 役割分担も明確化する必要がある。近年, PETの直接的な 予後的意義に関して懐疑的な報告も散見されており ${ }^{17-19)}$, 2016年に日本循環器学会より診療ガイドラインが示され たことから ${ }^{20)}$, PET撮像に関する, 前処置を含めた診療プ ラクティスの統一を図った上で, 多施設前向き共同研究に より, 免疫抑制療法中のFDG-PET所見の変化が持つ臨床
的意義を解明してゆく必要がある.

\section{今後の展望}

近年の著しい画像診断技術の進歩から, 直近 10 年間で 心臓サルコイドーシスの臨床診断精度は格段に向上した と言える。特に予後リスク層別におけるLGE-CMRの役割 は植込み型除細動器による突然死予防の観点からも極め て大きい21). 心臓サルコイドーシスは他の非虚血性心筋症 と比較し, 致死性不整脈などによる突然死リスクが高いこ とから ${ }^{22)}$, 植込み型除細動器の適応判断が重要であるが, 本邦においてエビデンスが不足しており，米国のガイドラ インと比較すると, その適応はやや消極的となってい $3^{20,23)}$ 。また, 低心機能・心不全の合併が多い本症では, デバイス留置例や腎不全例などLGE-CMR実施困難例も決 して少なくなく, 心電図やバイオマーカーなどによる致死 性不整脈・突然死リスク予測研究が急務である.

また, 本症は免疫抑制療法や心不全治療薬など標準治療 に対する治療反応性の個体差が大きいことも臨床的課題 である．実際，比較的早期に本症の確定診断に至ったにも かかわらず, 標準治療に対する反応がそしく, 突然死や進 行性の心機能低下による左室補助装置装着 - 心臓移植が 必要となる症例も少なくない. 近年, 科学技術の急速な進 歩により, マルチバイオマーカー, 多層オミックス解析な ど詳細な生体情報解析の循環器・ 心不全領域への応用が 期待されている ${ }^{24)}$. 心臓サルコイドーシスにおいても特徵 
的な遺伝子多型・代謝物の変化に着目した病態解明が可 能となり, 従来用いられていた臨床情報から得られた中間 表現型によるフェノタイピングだけでなく,より深い表現 型の探索（ディープフェノタイピング）を行い, 生命学的 背景の近い新規クラスター集団に心臓サルコイドーシス 症例を再分類することで, 高精度予後予測（特に致死性不 整脈・突然死）や薬物治療の個別化による新たな治療戦略 を構築できる可能性があり, 積極的に研究に取り組んでい きたいと考えている.

本研究の要旨は第 40 回日本サルコイドーシス/肉芽腫性 疾患学会総会（2020年10月30日, 大阪）で発表した。

\section{謝辞}

今回の受賞に関して, 本症の研究開始時から懇切丁寧な ご指導をいただきました北海道大学大学院医学研究院循 環病態内科学教室 安斉俊久教授, 慶應義塾大学循環器内 科学 香坂俊専任講師, そして病理組織学的検討において ご指導を賜りました国立循環器病研究センター病理部 植 田初江客員部長，池田善彦医長に深謝いたします。また， これまで学会等でご指導いただきました日本サルコイ ドーシス/肉芽腫性疾患学会の先生方に感謝申し上げま す.

\section{引用文献}

1) Sekiguchi M, Yazaki Y, Isobe M, et al. Cardiac sarcoidosis: diagnostic, prognostic, and therapeutic considerations. Cardiovasc Drugs Ther 1996; 10: 495-510.

2 ) Nagai T, Kohsaka S, Okuda S, et al. Incidence and prognostic significance of myocardial late gadolinium enhancement in patients with sarcoidosis without cardiac manifestation. Chest 2014; 146: 1064-72.

3 ) Patel MR, Cawley PJ, Heitner JF, et al. Detection of myocardial damage in patients with sarcoidosis. Circulation 2009; 120: 1969 77 .

4) Patel AR, Klein MR, Chandra S, et al. Myocardial damage in patients with sarcoidosis and preserved left ventricular systolic function: an observational study. Eur J Heart Fail 2011; 13: 12317.

5 ) Ekström K, Lehtonen J, Hänninen H, et al. Magnetic resonance imaging as a predictor of survival free of life-threatening arrhythmias and transplantation in cardiac sarcoidosis. J Am Heart Assoc 2016; 5: e003040.

6 ) Ise T, Hasegawa T, Morita Y, et al. Extensive late gadolinium enhancement on cardiovascular magnetic resonance predicts adverse outcomes and lack of improvement in LV function after steroid therapy in cardiac sarcoidosis. Heart 2014; 100: 1165-72.

7 ) Yazaki Y, Isobe M, Hiroe M, et al. Prognostic determinants of long-term survival in Japanese patients with cardiac sarcoidosis treated with prednisone. Am J Cardiol 2001; 88: 1006-10.

8 ) Nagai T, Nagano N, Sugano Y, et al. Effect of corticosteroid therapy on long-term clinical outcome and left ventricular func- tion in patients with cardiac sarcoidosis. Circ J 2015; 79: 1593600 .

9 ) Nagai T, Nagano N, Sugano Y, et al. Effect of discontinuation of prednisolone therapy on risk of cardiac mortality associated with worsening left ventricular dysfunction in cardiac sarcoidosis. Am J Cardiol 2016; 117: 966-71.

10) Morimoto S, Uemura A, Sugimoto K, et al. A proposal for diagnostic criteria of basal thinning of the interventricular septum in cardiac sarcoidosis (CS): a multicenter study. Circ J 2007; 70 (Supple I) : 215.

11) Nagano N, Nagai T, Sugano $Y$, et al. Association between basal thinning of interventricular septum and adverse long-term clinical outcomes in patients with cardiac sarcoidosis. Circ J 2015; 79: 1601-8.

12) Ardehali H, Howard DL, Hariri A, et al. A positive endomyocardial biopsy result for sarcoid is associated with poor prognosis in patients with initially unexplained cardiomyopathy. Am Heart J 2005; 150: 459-63.

13) Honda Y, Nagai T, Ikeda Y, et al. Myocardial immunocompetent cells and macrophage phenotypes as histopathological surrogates for diagnosis of cardiac sarcoidosis in Japanese. J Am Heart Assoc 2016; 5: e004019.

14) Komoriyama H, Omote K, Nagai T, et al. Lower left ventricular ejection fraction and higher serum angiotensin-converting enzyme activity are associated with histopathological diagnosis by endomyocardial biopsy in patients with cardiac sarcoidosis. Int J Cardiol 2020; 321: 113-7.

15) Tanaka TD, Nagai T, Nagoshi T, et al. Diagnosis of cardiac sarcoidosis despite negative findings on serial late gadolinium enhancement with cardiac magnetic resonance imaging/(18) F-fluorodeoxyglucose positron emission tomography examinations. J Nucl Cardiol 2020; 27: 2149-53.

16）永井利幸, 相川忠夫, 安斉俊久. 心臓サルコイドーシス診療にお けるFDG-PETによる活動性をガイドとした免疫抑制療法戦略の 限界. 日共会誌 2019; 39: 73-6.

17) Gowani Z, Habibi M, Okada DR, et al. Utility of cardiac magnetic resonance imaging versus cardiac positron emission tomography for risk stratification for ventricular arrhythmias in patients with cardiac sarcoidosis. Am J Cardiol 2020; 134: 123-9.

18) Manabe O, Koyanagawa K, Hirata K, et al. Prognostic value of ${ }^{18}$ F-FDG PET using texture analysis in cardiac sarcoidosis. JACC Cardiovasc Imaging 2020; 13: 1096-7.

19) Subramanian M, Swapna N, Ali AZ, et al. Pre-treatment myocardial ${ }^{18} \mathrm{FDG}$ uptake predicts response to immunosuppression in patients with cardiac sarcoidosis. JACC Cardiovasc Imaging 2021: S1936-878X (20)31024-X.

20) Terasaki F, Azuma A, Anzai T, et al. JCS 2016 guideline on diagnosis and treatment of cardiac sarcoidosis- digest version. Circ J 2019; 83: 2329-88.

21) Kazmirczak F, Chen KA, Adabag S, et al. Assessment of the 2017 AHA/ACC/HRS guideline recommendations for implant- 
able cardioverter-defibrillator implantation in cardiac sarcoidosis. Circ Arrhythm Electrophysiol 2019; 12: e007488.

22) Takaya Y, Kusano K, Nishii N, et al. Early and frequent defibrillator discharge in patients with cardiac sarcoidosis compared with patients with idiopathic dilated cardiomyopathy. Int J Cardiol 2017; 240: 302-6.

23) Al-Khatib SM, Stevenson WG, Ackerman MJ, et al. 2017 AHA/ ACC/HRS guideline for management of patients with ventricu- lar arrhythmias and the prevention of sudden cardiac death: a report of the American College of Cardiology/American Heart Association Task Force on clinical practice guidelines and the Heart Rhythm Society. Circulation 2018; 138: e272-e391.

24) Nagai T, Nakao M, Anzai T. Risk stratification towards precision medicine in heart failure- current progress and future perspectives. Circ J 2021; 85: 576-83. 